\title{
Heterotopia and the Failure of Pluralism in the Post-Internment Era: A Foucauldian Reading of John Okada's No-No Boy
}

By Ashraf Taha Mohamed Kouta, Ph.D. Lecturer of English Literature, Faculty of Arts, Damietta University, Egypt

\begin{abstract}
Based on Michel Foucault's concept of heterotopia as a theoretical framework, the present paper analyzes the dilemma of Japanese Americans as represented in No-No Boy (1957) by the Japanese American novelist John Okada (1923-1971). The paper seeks to add to the extant studies on the aftermath of the Second World War, particularly in relation to Japanese Americans and the repercussions of their internment experience. Foucault's concept of heterotopia adapts well to a reading of Okada's novel because it helps to find a link between bicultural tensions, the crisis of citizenship for Japanese Americans in the aftermath of the Second World War, and the idea of cultural pluralism as a major postmodern vision. By applying Foucault's concept of heterotopia, the paper proves that Okada's novel introduces a world in which diversity is not tolerated and minorities are considered heterotopias of deviation and crisis rather than essential constituents of a pluralist nation. The paper argues that the US created heterotopias by interning almost the entire minority of Japanese Americans and permanent Japanese residents inside concentration camps and prisons during the Second World War. Moreover, the paper demonstrates that the aftermath of the war as well as the internment experience marks the failure of cultural pluralism in America.
\end{abstract}

Keywords: Japanese Americans, internment, cultural pluralism, heterotopia, Michel Foucault, John Okada's No-No Boy

We have room for but one flag, the American flag ... We have room for but one language here, and that is the English language . . . and we have room for but one soul [sic] loyalty and that is a loyalty to the American people.

- Theodore Roosevelt, 26th President of the United States, 1919

(Qtd in Jackson and Perkins 90)

Applying Michel Foucault's concept of heterotopia to John Okada's novel No-No Boy (1957), the present paper delves into the binary correlation of hope and illusion embedded in the practice of cultural pluralism in the 
American society. More specifically, the paper deals with cultural pluralism in relation to Japanese Americans and their experience of internment during the Second World War and its repercussions on the issues of belonging and citizenship. Employing the concept of heterotopia, the present paper seeks to add a new dimension to the extant studies on Okada's No-No Boy. The paper argues that the US created counter-sites by interning almost the entire minority of Japanese Americans and permanent Japanese residents inside concentration camps and prisons during the Second World War. It is these exclusionary circumstances that have produced identity formation crises among Japanese Americans and have turned them into deviation and crisis groups .

Cultural pluralism is certainly one of the main constituent components of postmodernism. In its very core, cultural pluralism refers to the peaceful co-existence of several ethnicities with heterogeneous cultural backgrounds in a society where people, regardless of their ethnic background, language, religion and traditions, are guaranteed equality and freedom of practicing their own culture (Harvey 48). Horace Kallen (1882-1974), an American pluralist, strongly rejects the calls for assimilation. In this context, he emphasizes that "the existence of separate ethnic groups, even with separate cultures, religions, and languages, was consistent with democracy and other core American values" (Healey 49). But President Roosevelt's words in the above epigraph seem threatening to such vision. Although these words have been spoken out several decades before the arrival of postmodernism, they have survived well into the postmodern era and have menaced its growing spirit of pluralism. The pluralistic badge of postmodernism offers a model for co-existence and accepting minorities as part and parcel of the discursive practices of a given culture. This very vision, however, can be blurred and threatened if not accepted by all citizens on equal terms. This is what has happened in the case of Japanese Americans whose existence in America has become highly heterotopic.

Proposed by Michel Foucault (1926-1984), heterotopia is a concept used in postmodern literary criticism to refer to the co-existence of multiple inharmonious worlds. Critics agree in substance that the term heterotopia originally comes from medical sciences where it refers to parts of the body which are displaced and, consequently, malfunctioned or abnormal (Hetherington 42; Sudradjat 29). In literary criticism, heterotopia refers to 
the existence of certain different or abnormal spaces within a certain society. Foucault (1986), defines heterotopias as "counter-sites [which are] real places - places that do exist and that are formed in the very founding of society" (24). Since they are counter-sites, heterotopias are different from the mainstream culture; like body tumors, they represent the other within a given culture. In this connection, it has been argued that heterotopias are places of otherness (Burrows 165; Gordon 463; Hetherington viii; Dehaene and Cauter 3-4). For Foucault, there are certain principles of heterotopia which have to do with the forms, functions and characteristic features of heterotopias.

Foucault proposes six basic principles of heterotopia. First, heterotopias are spaces of crisis or deviation. These spaces are "reserved for individuals who are, in relation to society and to the human environment in which they live, in a state of crisis" (24). Therefore, individuals and social groups who inhabit these places are considered deviants and/or outcasts. Examples of deviation and crisis heterotopias are prisons, psychiatric hospitals and retirement homes which are meant to keep those who do not fit into the social order (25). Being places of deviation or crisis, heterotopias represent a state of abnormality and incompatibility within society. Second, each heterotopia has a certain function which is mainly determined by society. Being spaces that are kept for the deviant, heterotopias are meant to perform a positive function for they help in protecting society from the abnormal behavior of its outcasts. Ironically, however, heterotopias may perform functions other than the ones originally assigned to them. In this context, Foucault states that a society "can make an existing heterotopia function in a very different fashion" (25). The prison, for example, can be used to restrict political opponents, though its essential function is to keep criminals. Foucault's third and fourth principles of heterotopia highlight aspects of spatial and temporal incompatibility, respectively. A heterotopia is characterized by "juxtaposing in a single real place several spaces, several sites that are in themselves incompatible" (25). Prisons and slums are examples of spatial heterotopias where people of heterogeneous social and cultural backgrounds may live. On the other hand, it is argued that a place is heterotopic in terms of time if it accumulates within its limited space and its present existence several historical moments; i.e. it represents past times in the present moment. Japanese American enclaves, as depicted in Okada's novel, are meaningful examples of spatial and temporal heterotopias because these are places where incompatible generations of Japanese and Japanese Americans live together. The fifth principle of 
heterotopia has to do with its system of accessibility. Being different from the mainstream social order, a heterotopia "is not freely accessible like a public place. Either the entry is compulsory .... or else the individual has to submit to rites and purifications" (26). These accessibility requirements indicate that a heterotopia is a counter-site which is not open-accessed. According to Foucault's sixth principle, heterotopias can provide one of two spaces: a space of illusion, or a space of compensation. In this context, it is argued that since heterotopia is 'different,' it can create a space of illusion which is parallel to real spaces (27). An example is a prostitution house or a gambling club where people create an illusory space of happiness and entertainment. Still, it is just an illusion because it does not introduce solutions for social or psychological problems; it only gives some sort of sedations. On the other hand, a heterotopia can sometimes create a real, perfect space which compensates for the messy space in which we live (27). Heterotopia's role here is to provide a substitute for a reality that is not satisfactory. A good example is the hotel where all means and facilities of comfort are guaranteed .

The critical studies on Okada's No-No Boy can be divided into two major categories. The first category includes studies which focus on issues of Japanese American identity during and after the Second World War. Sarita Nyasha Cannon (2013), Francisco Delgado (2012), Jeanne Sokolowski (2009), Benzi Zhang (1999), and Stan Yogi (1996), among others, discuss the Japanese American's sense of alienation in America, and the protagonist's attempt to hold reconciliation and assimilation. Other critics such as Sbau-ling C. Wong and Jeffrey J. Santa Ana (1999) and Gayle K. Fujita Sato (1992) tackle the issue of identity from a feminist perspective, arguing that Ichiro's identity crisis is mainly a gendered one owing to the strong influence of his controlling mother. The second category of studies on No-No Boy includes a considerable number of critical works analyzing the novel from a psychological perspective. The trauma of the internment camps, the issues of displacement, disruption, anxieties, depression, despair, and the search for redemption and psychological adjustment are psychoanalytically treated by Seongho Yoon (2012), Joseph Entin (2010), James Davis (2009), Amy Gracia (2009), Fu-jen Chen (2007), Floyd Cheung and Bill E. Peterson (2006), Daniel Y. Kim (2005), Gary Storhoff (2004), Jinqi Ling (1995), and Dorothy Ritsuko McDonald (1979). Ling and McDonald refer to the influence of the mother on the psychological make-up of the protagonist; however, Bryn Gribben's "The Mother That Won't Reflect Back: 


\section{Ashraf Taha Mohamed Kouta, Ph.D.}

Situating Psychoanalysis and the Japanese Mother in No-No Boy" (2003) and Wenying Xu's "Sticky Rice Balls or Lemon Pie: Enjoyment and Ethnic Identities in No-No Boy and Obasan" (2002) are the most prominent examples of the employment of feminist psychoanalysis to the analysis of the role of the controlling mother in the life and decisions of Okada's protagonist. On the other hand, the current paper analyzes the heterotopic conditions that have made such interpretations possible.

Since their arrival in the New World, certain preconceived notions about Asian Americans have circulated and determined how they have been treated. For example, several historians such as William F. Wu and Gina Marchetti argue that an Asian American is seen by many white Americans as a 'yellow peril,' an epithet that has stigmatized the Asian American as a source of threat to the American community and the purity of its whiteness. This yellow-peril hysteria reflects "racist terror of alien cultures, sexual anxieties, and the belief that the West will be overpowered and enveloped by the irresistible, dark, occult forces of the East" (Marchetti 2). The yellow-peril anxiety has become widespread through journalism and scientific discourse which has seen the Asian immigrant as "a cancer in the biological, social, religious and political systems" (Adams 30). Interestingly enough, likening the existence of Asians in America to a 'cancer' recalls Foucault's concept of heterotopia. In other words, Asians in America have been considered as dangerous and abnormal as tumours in the body. Consequently, they have been socially rejected. In February 1905, referring to the impossibility of integrating Japanese people in the American community, the San Francisco Chronicle stated that "[t]he Asiatic can never be other than an Asiatic, however much he may imitate the dress of the white man, learn his language and spend his wages for him" (qtd in Okihiro 105). In July 1920, the Los Angeles Times also asserted that the "assimilation of whites and Japanese was not only 'unthinkable' and 'morally indefensible,' it was 'biologically impossible'" (105). Moreover, the economic factors have also played a vital role in discriminating against Asian Americans. Most Asians have been employed in mining industries and sugar plantations for wages much less than those paid for white laborers, i.e. they have been treated as a cheap labor power. Their acceptance to work as cheap laborers, however, has ignited the hostility of white laborers against them. (Okihiro 105-9)

Consequently, Asian Americans in general, and Japanese Americans in particular, have been exposed to certain exclusionary procedures which 
have aimed to keep them in line and restrict their mobility. Gary Y. Okihiro calls the period from 1882 to 1965 "the period of exclusion" in so far as Asian Americans are concerned (35). The most horrible exclusionary act in modern American history, however, happened during the Second World War when Japanese Americans were collectively interned in ten concentration camps. On the seventh of December, 1941, the Imperial Japanese Navy attacked the American naval base at Pearl Harbor, causing the death of 2402 Americans. As a result, Executive Order 9066 was signed by President Franklin D. Roosevelt in February 1942 whereby over 120,000 Issei, Nisei and Sansei people, mainly from the West Coast, were temporarily gathered into assembly centers for few months, then they were forced to be relocated into internment camps (Adams 52-53). Ironically, a great number of those internees were citizens of the US. In 1943, internees were forced to fill in a loyalty questionnaire form which proved controversial particularly in its 27th and 28th questions:

ivAre you willing to serve in the armed forces of the United States on combat duty wherever ordered?

. $\wedge$ Will you swear unqualified allegiance to the United States of America and faithfully defend the United States from any or all attack by foreign or domestic forces, and forswear any form of allegiance or obedience to the Japanese emperor, to any other foreign government, power, or organization? (Neg 161)

Japanese Americans who have negatively responded to the two questions have come to be known as 'no-no boys' and have been forced to live in prison for several years. For many critics, the internment of Japanese Americans is considered a fervent expression of American racism against minorities in general and Japanese Americans in particular (Marchetti 154; Adams 12, 53; Okihiro 103; Yogi 63). The forced internment of Japanese Americans has been a grievous mistake whose legacy has marked the failure of American democracy of which pluralism is one fundamental aspect. Above all, the internment shows that Japanese Americans have been treated as mere pariahs inhabiting crisis or deviation heterotopias.

Set in Seattle immediately after the end of the Second World War, Okada's No-No Boy tells the story of Ichiro Yamada, a 25-year old Japanese American Nisei boy who has just come back to his Japanese 
American community after two years in internment camp and two years in prison for answering no-no to the loyalty questionnaire. In a series of flashbacks, characters dwell on their past lives and attribute their misery to the experience of internment camps during the Second World War. This experience clearly shows that the American spirit of pluralism has been drastically shaken. Released from prison, Ichiro finds himself despised and rejected by both friends and strangers; he "leaves an internment prison only to return home to a different form of prison, one without physical bars, but more difficult from which to break" (Gracia 166). Walking down a Seattle street, he "felt like an intruder in a world to which he had no claim" (No-No Boy 1). Therefore, being a no-no boy, Ichiro feels alone against a world which seems to reject diversity. However, he strives to carve out a new meaning for his disturbed life, hoping that one day he could be accepted again as an American citizen .

The internment camps where Ichiro and other Japanese Americans have been detained during the Second World War are considered heterotopias of crisis and deviation in the Foucauldian sense. Interning a whole minority without regard to their civil rights and without any distinction between loyal and disloyal persons means that the people of Japanese ancestry have been collectively seen as deviants whose movements should be circumscribed. This behavior is anomalous and illegal. In 1941, President Roosevelt asked his confidante John Franklin Carter to undertake an intelligence study of Japanese and Japanese Americans living on the West Coast. The reports submitted to the president state that Japanese Americans are "universally estimated from 90 to $98 \%$ loyal to the United States" (Muller 15). This clearly indicates that this massive action has been unnecessary. In the preface to No-No Boy, Okada states that the immediate outcome of the Pearl Harbor attack is that Japanese Americans have become "animals of a different breed" (iii). Since the original function of heterotopia is to keep the abnormal and socially deviant persons away from society, as Foucault states, the internment camps here become crisis and deviation heterotopias and Japanese Americans are collectively considered a group of deviants and social pariahs. What makes Ichiro and his people feel bitter is that "without charges, without proof, without hearings ... they were herded into makeshift barracks at racetracks and fairgrounds" (Muller 21). Prisons here are manipulated to coerce and segregate a whole minority based on racial assumptions. Using flashback, the third-person narrator of No-No Boy restates the racial dilemma of Ichiro and many other internees who refuse to serve in the American army and to swear alliance to the USA. 
Their refusal stems from their feeling that they are racially oppressed. Facing the judge, Ichiro bursts out: "You can't make me go in the army because I'm not an American or you wouldn't have plucked me and mine from a life that was good and real and meaningful and fenced me in the desert like they do the Jews in Germany." (No-No Boy 31)

Hence, internment camps are considered spatiotemporal heterotopias. According to Foucault, those who are in a state of crisis in relation to society are often separated in desolate areas outside the vivid life of society. These internment camps are heterotopic places because they are located outside the main centers of the city. As Ichiro reflects, even Nisei boys who enjoy full American citizenship are sent to "the relocation camp out in the God-awful desert" (No-No Boy 232). As counter-sites, internment camps are depicted as spaces of the dead. Gary, a no-no boy, tells Ichiro: "I rotted in prison ... I died in prison" (223). Here, the prison becomes a heterotopia of crisis. After he leaves prison, Gary feels that he has come out of the grave. He says to Ichiro: "I feel like a guy that's come back from the dead" (226). Ichiro, too, must have metaphorically died in prison. Japanese Americans are symbolically dead people inside prisons which are similar to the cemetery as one form of spatial heterotopia (Foucault 26). This implies that people of Japanese ancestry "do not exist in the symbolic order. Because they are not granted subjective positions, they are the living dead" (Chen 116). Internment camps are considered spatial heterotopias because they are sites where Japanese Americans are excluded from the dominant social order; they are isolated and confined in prisons that are located in desolate areas. By setting up assembly centers and then permanent internment camps for Japanese Americans, the white American society isolates the whole minority of Japanese Americans who are not seen as part of that society, thus creating spatial heterotopias. Talking about the experience of the evacuation, internment and the war itself, Kenji, a Japanese American veteran, tells Ichiro that the "government put them in camps and put real fences around them" (No-No Boy 164). The American Legion Magazine has even called the internment camps "Little Tokyos" (Howard 224). It is here that internment camps have become spatial heterotopias or counter-sites in which Japanese Americans are considered aliens .

Being different from the mainstream social order, heterotopias, like prisons and concentration camps, have a certain accessibility system, according to Foucault's fifth principle. The heterotopic site is not freely 


\section{Ashraf Taha Mohamed Kouta, Ph.D.}

accessible. Generally, the entry to such heterotopias is obligatory, but leaving them may require certain rites and purifications, as Foucault states. The camps where Japanese Americans have been confined differ greatly from normal civil life because of their strict style. That is, the construction of these camps as well as the style of living there follow military models: "A siren alarm blast rang every morning at 7 A.M. ... Camp life was highly regimented and it was rushing to the wash basin to beat the other groups, rushing to the mess hall for breakfast, lunch, and dinner" ( $\mathrm{Ng}$ 42). Japanese Americans have been forced to enter internment camps, but later, after two years of compulsory internment, the US has introduced a questionnaire through which Japanese Americans are either to be confined to prison, whose entry is compulsory, or to pass through a process of rites and purifications so that they might go back to normal life. This process involves accepting loyalty to the US army by joining the war against Japan and other enemies. This questionnaire represents the real crisis which faces Okada's characters in No-No Boy.

The loyalty questionnaire indicates that the American society looks at the Japanese American community as a kind of crisis or deviation heterotopia whose residents are aliens and outcasts of society. In particular, Questions 27 and 28 have outraged Japanese American internees. Nisei young men who have enjoyed full American citizenship are particularly irritated by the questionnaire which has obviously revealed that the American regime looks at them as being Japanese enemies only because they have Japanese roots. Explaining why he has decided to give a double negative answer to the two questions of the questionnaire, Ichiro says to Mr. Carrick: "I haven't much choice ... First they jerked us off the Coast and put us in camps to prove to us that we weren't American enough to be trusted. Then they wanted to draft us into the army. I was bitter - mad and bitter" (No-No Boy 152-3). Therefore, Ichiro and other young Japanese Americans find themselves torn between the sense of loyalty they have for America and the bitter reality of internment. It is here that Ichiro's rejection of serving in the American army, according to McDonald, "is understandable" taking into consideration the fact that he has been "deprived of home, property, and family, and moved into a barren desert against his will" (19). In other words, Ichiro's double-negative answer to the loyalty questionnaire is a rejection of the unjust and unjustified internment of Japanese Americans rather than a rejection of America itself.

A point that is worth emphasizing is that the whole process of internment as well as the ensuing questionnaire signifies the failure of the pluralist 
American spirit. Detaining a whole minority because they are different reveals an implied rejection of cultural diversity and a rejection of the other in the American culture. That is because Japanese Americans are forced to blot out their Japanese roots which form an essential part of their identity. For Japanese American internees, the questionnaire "required distaste for their parents and their culture and, ultimately, a veiled self-hatred" (Yogi 65). It is here that the questionnaire denies difference and classifies internees into loyal and disloyal. Culturally, being loyal to one's roots, heritage, language and traditions does not necessarily mean that one is disloyal to the land of his/her residence or birth. This binary opposition 'loyal' or 'disloyal' is dangerous to pluralism in which the members of a minority can maintain their own cultural heritage as long as they do not violate the common system of the society in which they live. This very binary opposition haunts Ichiro as he leaves his prison and goes back to his Japanese American community in Seattle. It shatters the stability of the pre-war time and turns Japanese American communities into highly heterotopic spaces that teem with social, ideological and psychological contradictions.

In the aftermath of internment, Japanese Americans come to find more blatant forms of heterotopia. The internment experience has created heterotopic conditions and led to an obvious ideological division among Japanese Americans. According to Joan Gordon, "as people are cast off from society, they form a counter-society, a counter-site of their own. To the society that casts its deviants aside, these institutions are deviation heterotopias" (466). Hence, the Japanese American community is seen as a counter-site, a deviation heterotopia whose residents are mere outcasts. Here comes Foucault's third principle of heterotopia. For him, heterotopia means "the coexistence in 'an impossible space' of a 'large number of fragmentary possible worlds' or, more simply, incommensurable spaces that are juxtaposed or superimposed upon each other" (Harvey 48). As No-No Boy shows, within a limited space, there live heterogeneous Japanese Americans. That is, after the war, both veterans and prisoners come back to their Japanese American enclaves, forming highly heterotopic spaces. The protagonist of Okada's novel finds himself torn between two incongruous worlds: the world of his Japanese folks with its incompatible elements and views concerning America and Japan, and the world of white people for whom all Japanese Americans, whether they are loyal or not, are just aliens and yellow perils. 


\section{Ashraf Taha Mohamed Kouta, Ph.D.}

Being counter-places allocated for the socially abnormal, Japanese American enclaves are characterized by inhuman conditions. The novel is full of images of ugliness and filthiness as one aspect of heterotopia. Seattle, where Ichiro comes to live in the post-internment era, is depicted as a sort of spatial heterotopia. Early in the novel, Ichiro comes back from prison to find Seattle "a dirty city ... Dirtier, certainly than it had a right to be" (No-No Boy 7). These images accompany Ichiro and his friend Kenji as they walk in the streets of Seattle: "They walked down the ugly street with the ugly buildings among the ugly people which was a part of America and, at the same time, would never be wholly America" (71). Ichiro notices that the buildings are dilapidated and the streets are dirty with a lot of tramps, drunkards and gamblers. He describes his world as "a rotten place, rotten and filthy and cheap and smelly" (159). Ichiro's home also mirrors his mental prison; it is just "a hole in the wall with groceries crammed in orderly confusion on not enough shelving, into not enough space" (6). The Japanese American community has only one major club, the Club Oriental. The club is a dangerous place where violence often takes place. In one of these scenes of violence, Freddie, Ichiro's friend, is killed after a fight with Bull, another Japanese American.

Returning from prison, Ichiro feels displaced. He finds both his family and community fractured and caught in the binary dichotomy of 'Japanese' and 'American.' The hard experience of internment has caused social as well as psychological cleavage for Japanese Americans. Such cleavage is very obvious in Ichiro's family. For example, Ichiro's younger brother, Taro, is completely loyal to America, the country of his birth. He hates all the members of his family and determines to join the American army once he turns eighteen years old in order to atone for Ichiro's no-no status. Taro even shows his loyalty to America by betraying his own brother. He traps Ichiro and leads him out of the Club Oriental where Taro's friends fiercely assault him (No-No Boy 78-79). On the contrary, disoriented by the harsh experience of internment and the Second World War, Ichiro's mother becomes a Japanese loyalist. She welcomes Ichiro home after spending two years in prison: "I am proud to call you my son" (11). Japan here occupies a virtual space; it exists in the minds and behavior of those characters and, whether positively or negatively, affects their daily life and the decisions they take. Although her sons are American by birth, the mother forces the image of Japan on them. 
In this context, Foucault's reference to the mirror as a sort of utopia is significant because it epitomizes the dilemma of Japanese Americans like the mother. For him, the mirror represents "a sort of mixed, joint experience" between utopias and heterotopias (Foucault 24). He argues that the mirror is a utopia because "it is a placeless place" (24). In other words, the mirror is a virtual space where a person sees himself/herself, though he/she is not really there. Similarly, while Ichiro's mother is living in Seattle, that is part of the US, her whole being, actions and dreams revolve around Japan. Although she is in America, she sees the reflection of Japan in the virtual space around her as well as within her. As Ichiro believes, his mother "breathed the air of America and yet had never lifted a foot from the land that was Japan" (No-No Boy 11). She claims that Japan has won the war and that the Emperor will send ships to take them back to the affluent land of Japan. In reality, the superfluous Japan that the mother and some other Japanese Americans believe in does not exist; it is their own utopia, an unreal space that exists only in their imagination. When those characters eventually discover that the utopia of Japan does not really exist, their heterotopic reality in America is augmented. In a moment, the two worlds which constitute the mother's heterotopia, namely the American reality and the Japanese virtual reality, collapse and she finds herself in nowhere, a state of nothingness and utter emptiness. It is here that she willingly decides to end this state of utter despair by committing suicide ()$\left.^{\wedge} 0\right)$.

The Japanese American war veterans represent another component of Japanese American heterotopias. Although they have proved their loyalty to America during the Second World War, they have come to realize that they are still considered abnormal parts of the American community: "They think just because they went and packed a rifle they're different but they aren't and they know it. They're still Japs" (No-No Boy 163). Throughout the novel, 'Jap' as a racial epithet is used to refer to all Japanese and Japanese Americans whether they have shown their loyalty or not. Kenji bitterly tells Ichiro that, for white Americans, both loyal and disloyal Japanese Americans are just "a bunch of Japs with a fence around them" (164). Kenji's reference to the fence here asserts that Japanese American enclaves are considered counter-sites inhabited by aliens and outcasts. Consequently, even after leaving internment, Japanese Americans, like criminals and deviants, are still segregated from the mainstream of American society. 


\section{Ashraf Taha Mohamed Kouta, Ph.D.}

Interestingly, the incompatibility of Japanese American enclaves is represented in the novel through Kenji's incompatible body parts. Kenji lost one of his two legs while fighting for America in the Second World War. The amputation of his leg is caused by the very war experience which has been responsible for turning Japanese American communities into counter-sites. Accordingly, his body exemplifies how the US itself is responsible for the trauma of Japanese Americans. Taking into consideration the fact that the word 'heterotopia' is mainly a medical term associated with body tumors and displaced bodily parts, Kenji's leg amputation shows how he is a social pariah; his body parts are incompatible, as is the case of Japanese Americans in the US mainstream culture. The cleavage within his body symbolizes the cleavage that marks the unsound relationships among Japanese Americans.

These heterotopic conditions within Japanese American enclaves lead to another social and psychological war among Japanese Americans who come to be classified as loyal and disloyal. Rejected by the white community for being of Japanese ancestry, Nisei soldiers suffer from projection and a deep-down sense of inferiority. They come to be hostile towards no-no boys, regarding them as "a stain on their community" (Yoon 49). As a no-no boy, Gary tells Ichiro that when yes-yes boys "find out they're still Japs, they'll be too busy to be mean to us" (No-No Boy 227). This stinging inferiority complex is evident right from the beginning of the opening scene of the novel in which Eto Minato, a Nisei soldier, meets Ichiro. Like other Nisei veterans, Eto uses the epithet 'Jap' in an attempt to separate himself from his fellow Japanese Americans: "Lotsa Japs coming back to the Coast. Lotsa Japs in Seattle .... Japs are funny that way" (2). When Eto realizes that Ichiro is a no-no boy, he projects his own self-hatred and sense of inferiority on him; he spits on Ichiro and calls him a "rotten bastard" (4). Within Foucault's interpretation of the concept of heterotopia, this hostile scene at the beginning of the novel indicates that the Japanese American community Ichiro is heading to after four years of imprisonment is a kind of heterotopia caused mainly by the experience of internment. Bull is another Nisei veteran who dissociates himself from anything related to the Japanese community. For example, he always shows his red-haired girlfriend before other Japanese Americans. He also reveals his hatred of Japanese Americans by assaulting and humiliating them. Fighting with Ichiro and Freddie, Bull yells at them: "I wasn't fightin' my friggin' war for shits like you" (247). In short, Nisei veterans remain part of the Japanese American counter-sites, and their dreams of assimilation into 
the mainstream of American culture reveal that theirs is a heterotopia of illusion .

The Club Oriental is a representation of what Foucault calls the heterotopia of illusion which surrounds many Japanese Americans in the novel. Examples of illusory spaces are prostitution houses and gambling clubs where people escape from real life, creating moments of happiness through drinking, sex, gambling, and drugs. The club is referred to as "a bottle club" that provides its members with drinks "and rang up heft profits nightly" (No- No Boy 71). Attempting to forget about their troubles, Ichiro and Kenji, like many other Japanese Americans, go to the club to spend a night of drinks and gambling. Feeling content that he is in the bar, Kenji tells Ichiro that he hopes to spend his life inside the club. Thinking about the worthless sacrifices he has done, Kenji even hopes to "sell the car and spend the rest of my life sitting here with a drink in my hand and feeling good" (73). Humiliated by Bull, Ichiro, too, drinks heavily, "hoping to find escape in the whiskey" (75). But this is not a sort of real happiness; it is a mere form of illusion because once they get out of the club, they will get back to their miserable reality. The narrator here recalls death imagery to show that Japanese Americans like Ichiro and Kenji are symbolically dead even if they attempt to create an illusory space of happiness: "So they sat silently through the next drink, one already dead but still alive and contemplating fifty or sixty years more of dead aliveness, and the other, living and dying slowly" (73). Since Japanese Americans are symbolically dead, their community is a heterotopia of illusion because they think they are alive while they are actually not. In addition to drinking, sex is part and parcel of the illusory space Japanese Americans create to escape their plight. Like Bull and Freddie, Ichiro finds solace in having sex. For example, after Ichiro is humiliated by Bull and Taro, Kenji takes him to a Japanese American girlfriend, Emi, who helps him overcome the trauma by sleeping with $\operatorname{him}\left(9 r_{-} \wedge r\right)$.

Ichiro, however, attempts to go beyond this heterotopia of illusion, hoping for reconciliation and compensation. The inharmonious conditions within counter-sites may lead some of their inhabitants to seek to improve these conditions and compensate for their misery, creating what Foucault calls "the heterotopia, not of illusion, but of compensation" (27). Ichiro's search for compensation is clear early in the novel. No sooner does he leave prison than his dream of creating a space of compensation starts. 


\section{Ashraf Taha Mohamed Kouta, Ph.D.}

His aim is to reach a state in which he feels proud of being both Japanese and American. The solution of his dilemma is not in cutting ties with his Japanese heritage and becoming fully assimilated in the American style of life like Bull, Eto and Taro, nor is it in becoming hostile to American culture like Freddie. The solution resides in cultural pluralism which is supposed to be part and parcel of American democracy. In theory, pluralism allows minorities to participate in the mainstream culture without forgetting all about their heritage. It is in integrating the American and Japanese cultures that Ichiro may find his true identity. As Gribben puts it, the identity which Ichiro "aspires to allows no 'halves,' only wholes" (40). Believing in American democracy, Ichiro hopes to be both Japanese and American. He yearns for the pluralist spirit which could allow him to be "Japanese with Japanese feelings and Japanese pride and Japanese thoughts" as well as a loyal American because "one is not born in America and raised in America and taught in America ... without becoming American and loving it." (No-No Boy 15-16)

As a step towards achieving this pluralist vision, Ichiro eventually sympathizes with his mother. Although he hates her for being responsible for his dilemma, he comes to excuse her because Japanese Americans cannot obliterate their historical relations with Japan. He delves deeply into the causes of her hatred of America, trying to justify her actions. He asks: "Was it she who was wrong and crazy not to have found in herself the capability to accept a country which repeatedly refused to accept her or her sons unquestioningly?" (No-No Boy 104). This very question seems to indict America of violating its own principles of pluralism. While America requires minorities to be fully loyal to it, America itself looks at them as mere yellow perils. That is why Ichiro comes to doubt his mother's responsibility for his no-no status: "Sometimes I think my mother is to blame. Sometimes I think it's bigger than her" (152). Therefore, Ichiro decides to return home, recognizing that his Japanese parents are an indispensable part of him. That part he should reconcile in order to move from a state of fragmentation to one of reconciliation and compensation. When he returns home, however, he discovers that his mother has just committed suicide after acknowledging the defeat of Japan. As he carries his dead mother, Ichiro seems to bear no grudge for her: "I feel sorry for you. Not sorry that you are dead but sorry for the happiness you have not known ... I want very much for you to know the happiness that you tried so hard to give me" $(186,187)$. By showing sympathy towards the immigrant generation, represented in his mother, 
Ichiro accepts his Japanese heritage as an integral part of his own identity as an American.

Having achieved internal reconciliation, Ichiro strives to extend his vision of redemption and compensation to include all ethnicities. He wants to accept, and be accepted by, the whole community. Dancing with Emi at a roadside restaurant immediately after his mother's funeral, he reflects: "I've got to love the world the way I used to. I've got to love it and the people so I'll feel good" (No-No Boy 209). Ichiro here considers the dancing hall a space of compensation. Being a place open for all ethnicities and social groups, the hall seems to be a representation of the way of life he aspires to: a harmonious social framework based on diversity. Ichiro feels that he has found the pluralistic spirit he has been looking for. He wonders: "Why can't it be that way for me? Nobody's looking twice at us. Nobody's asking me where I was during the war or what the hell I am doing back on the coast" (209). The time Ichiro spends dancing with Emi is healing because it allows him to envisage the possibility of a future in which Japanese Americans like him may have a place in society. Commenting on this scene, Yogi considers the dance floor "a metaphor for America" (72). More specifically, the dance floor symbolizes the diverse America that Ichiro dreams of, a place where ethnic differences do not matter. This spirit of diversity seems to be ascertained when a drunken white man insists on buying drinks for Ichiro and Emi. Although the man does not account for his behavior, he seems friendly, and Ichiro interprets it in the light of his pluralistic vision: "I want to think ... that he saw a young couple and liked their looks and felt he wanted to buy them a drink and did" (No-No Boy 211). Ichiro here provides an explanation which is free from ethnic background; he sees himself and Emi as 'a young couple' rather than a Japanese American couple .

Before the end of the novel, Ichiro experiences another seemingly healing situation. After a fierce fight outside the Club Oriental between Ichiro's friend Freddie and the aggressive Japanese American veteran Bull, Freddie attempts to escape but his car hits a building and he immediately dies. When Bull knows that Freddie has died, he weeps "not like a man in grief or a soldier in pain, but like a baby in loud, gasping, beseeching howls" (No-No Boy 250). Although Bull has always been Ichiro's tormentor, Ichiro, having just achieved internal reconciliation, feels sympathetic towards him: "Ichiro put a hand on his [Bull's] 


\section{Ashraf Taha Mohamed Kouta, Ph.D.}

shoulder, sharing the empty sorrow in the hulking body, feeling the terrible loneliness of the distressed wails, and saying nothing. He gave the shoulder a tender squeeze, patted the head once tenderly" (250). Here, Ichiro does not hesitate to bestow upon Bull the sense of healing he yearns to throughout the novel. Interpreted in the light of Foucault's sixth principle of heterotopia, the end of the novel shows that Okada attempts to create a space of compensation which is based on healing and reconciliation. Bull's baby-like weeping seems to be a rebirth metaphor that alludes to the possibility of healing the ordeal of the past.

Although the end of the novel alludes to the hopes of redemption through these moments of healing, such hopes seem very faint. Using a circular narrative style, Okada allows the novel to end where it begins with mere hopes of integration. On the very first page of the text, Ichiro wonders: "Was there no hope of redemption? Surely there must be" (NoNo Boy 51). In the last paragraph of the text, he is still searching for an answer to the same question: "A glimmer of hope - was that it? It was there, someplace. He couldn't put it into words, but the feeling was pretty strong" (250-51). Thus, the end of the novel presents mere hopes for redemption and compensation. After leaving Bull weeping like a baby, Ichiro walks alone, thinking about the future: "He walked along, thinking, searching, thinking and probing, and, in the darkness of the alley of the community that was a tiny bit of America, he chased that faint and elusive insinuation of promise as it continued to take shape in mind and in heart" (251). The use of words like 'glimmer,' 'faint' and 'elusive' assert that the hopes and promises of redemption and compensation are too feeble to rely on. Ironically, it seems that Ichiro's hopes form for him a mere virtual reality, an unreal space that has nothing to do with an unwelcoming white world that looks at him as "an underground man" (Gray 772). By the end of the novel, Ichiro is still thinking and hoping but nothing has been actually achieved. In other words, while Okada's protagonist accepts America, it is not clear whether America will accept him or not.

In conclusion, the mass internment of Japanese Americans and its aftermath mark the failure of cultural pluralism. Incarcerating almost 120,000 Japanese Americans in ten segregated concentration camps and using a questionnaire to force internees to choose between Japan and America is a polarized idea that violates the very foundations of America as a diverse nation. The internment plight shows that Japanese Americans as a minority group are not tolerated. It is here that cultural pluralism is 
menaced because Japanese Americans, whether they like it or not, have at least moral and psychological links connecting them to their motherland. Besides, the questionnaire itself subverts the idea of plurality in that it predetermines that these people are to be suspected and, therefore, their American citizenship is violated. Hence, Ichiro's double negative answer to the questionnaire is not a rejection of loyalty to America or a refusal to serve in its army. Rather, it is a rejection of that binary opposition of 'Japan' or 'America.' That is, it is a denunciation of the polarized and narrow vision that violates the pluralist spirit of American democracy. In other words, while yes-yes boys accept to serve in the American army to prove that they are true Americans, no-no boys prefer to say no, not to America per se, but to the bigotry and racism that threaten to subvert the American Dream with its idealistic promises of pluralism.

Although the possibility of a better future is proposed in the last lines of the text, the author leaves us uncertain about the future of things. All the attempts of reconciliation are proposed merely by Ichiro. When the novel ends, it is not clear how long Ichiro will wait and what rites of purifications he has to pass through before he could be allowed to leave his heterotopic space and be recognized as a full-fledged American citizen. It is also unclear whether the pluralist spirit of America will be revived, a spirit whose absence is responsible for the creation of heterotopic spaces within the American society. In reality, America for Ichiro is just a mirror, a non-existing utopia. He lives in America and carries its citizenship but remains outside of its national narrative. In the end, although Ichiro yearns for redemption and reconciliation with the American society at large, he remains a mere outcast inhabiting a heterotopia of illusion where he continues to think, probe and hope .

\section{Notes}




\section{Ashraf Taha Mohamed Kouta, Ph.D.}

\section{Works Cited}

Adams, Bella. Asian American Literature. Edinburgh: Edinburgh UP, 2008. Print.

Cannon, Sarita Nyasha. "Shattering the Binary: Teaching Critical Thinking through John Okada's No-No Boy." Asian American Literature: Discourses and Pedagogies 4 (2013): 15-29. Web. 8 April 2017.

Chen, Fu-jen. "A Lacanian Reading of No-No Boy and Obasan: Traumatic Thing and Transformation into Subjects of Jouissance." The Comparatist 31 (May 2007): 105-129. MUSE. Web. 26 March 2017.

Cheung, Floyd, and Bill E. Peterson, "Psychology and Asian American Literature: Application of the Life-Story Model of Identity to No-No Boy." The New Centennial Review 6.2 (Fall 2006): 191-204. MUSE. Web. 26 March 2017.

Davis, James. "Ichiro is a Punk, and other Lessons from Teaching: The Immigrant Experience." The Radical Teacher 84 (Spring 2009): 50-61. JSTOR. Web. 17 March 2017.

Dehaene, Michiel, and Lieven de Cauter, eds. Heterotopia and the City: Public Space in a Postcivil Society. London, Routledge, 2008. PDF .

Delgado, Francisco. "Neither Japanese Nor American: Identity and Citizenship in John Okada's No---No Boy". Trespassing Journal 1 (Spring 2012): 50-61. Web. 17 Jan. 2017.

Entin, Joseph. "A Terribly Incomplete Thing: No-No Boy and the Ugly Feelings of Noir." MELUS 35.3 (Fall 2010): 85-104. JSTOR. Web. 19 Feb. 2017 .

Foucault, Michel. "Of Other Spaces." Trans. Jay Miskowiec. Diacritics 16.1 (Spring 1986): 22-27. JSTOR. Web. 19 Nov. 2016.

Gordon, Joan. "Hybridity, Heterotopia, and Mateship in China Miéville's "Perdido Street Station." Science Fiction Studies 30.3 (Nov. 2003): 456-76. JSTOR. Web. 22 Nov. 2016.

Gracia, Amy. "Streets of Despair and Blocks of Hope in John Okada's No-No Boy." Undergraduate Review 5 (2009): 166-69. Web. 12 Jan. 2017.

Gray, Richard. History of American Literature. 2nd ed. Oxford: WileyBlackwel, 2012. PDF. 
Gribben, Bryn. "The Mother that Won't Reflect Back: Situating Psychoanalysis and the Japanese Mother in No-No Boy." MELUS 28.2 (Summer 2003): 3146. JSTOR. Web .

Harvey, David. The Condition of Postmodernity: An Enquiry into the Origins of Cultural Change. 2nd ed. Cambridge: Blackwell Publishers, 1992. PDF.

Healey, Joseph F. Diversity and Society: Race, Ethnicity and Gender. 4th ed. London: SAGE Publications, 2014. PDF .

Hetherington, Kevin. The Badlands of Modernity: Heterotopia and Social Ordering. London: Routledge, 1997. PDF.

Howard, John. Concentration Camps on the Home Front: Japanese Americans in the House of Jim Crow. Chicago: The University of Chicago Press, 2008. Print.

Huang, Guiyou, ed. The Greenwood encyclopedia of Asian American literature. 3 Vols. Westport: Greenwood Press, 2009. PDF .

Jackson, Harry R., Jr., and Tony Perkins. Personal Faith, Public Policy. Florida: FrontLine, 2008. Google Book Search. Web. 22 Dec. 2017.

Kim, Daniel Y. "Once More, with Feeling: Cold War Masculinity and the Sentiment of Patriotism in John Okada's No-No Boy." Criticism 47.1 (Winter 2005): 65-83. JSTOR. Web. 19 Jan. 2017.

Lim, Shirley Geok-lin, and Amy Ling, eds. Reading the Literatures of Asian America. Philadelphia: Temple UP, 1992. PDF.

Ling, Jinqi. "Race, Power, and Cultural Politics in John Okada's No-No Boy." American Literature 67.2 (June 1995): 359-81. JSTOR. Web. 19 Jan. 2017.

Marchetti, Gina. Romance and the "Yellow Peril": Race, Sex, and Discursive Strategies in Hollywood Fiction. Berkeley: University of California Press, 1993. Print.

McDonald, Dorothy Ritsuko. "After Imprisonment: Ichiro's Search for Redemption in No-No Boy." MELUS 6.3 (1979): 19-26. JSTOR. Web. 22 Jan. 2017. 


\section{Ashraf Taha Mohamed Kouta, Ph.D.}

Muller, Eric L. American Inquisition: The Hunt for Japanese American Disloyalty in World War II. Chapel Hill: U of North Carolina P, 2007. PDF.

Ng, Wendy. Westport, Connecticut Japanese American Internment during World War II: A History and Reference Guide. Westport: Greenwood Press, 2002. PDF.

Okada, John. No-No Boy. Seattle: University of Washington Press, 1979. Print.

Okihiro, Gary Y. The Columbia Guide to Asian American History. New York: Columbia UP. 2001. Print .

Sato, Gayle K. Fujita. "Momotaro's Exile: John Okada's No-No Boy." In Lim and Ling 239-58.

Storhoff, Gary. "A Prisoner of Forever": Cognitive Distortions and Depression in John Okada's No-No Boy." Interdisciplinary Literary Studies 6.1 (Fall 2004): 1-20. JSTOR. Web. 19 Feb. 2017.

Sokolowski, Jeanne. "Internment and Post-War Japanese American Literature: Toward a Theory of Divine Citizenship." MELUS 34.1 (Spring, 2009): 69- 93. JSTOR. Web. 22 Jan. 2017.

Sudradjat, Iwan. "Foucault, the Other Spaces, and Human Behaviour." Procedia - Social and Behavioral Sciences 36 (2012) 28-34. Elsevier. Web. 11 Dec. 2016 .

Wong, Sau-ling C. and Jeffrey J. Santa Ana. "Gender and Sexuality in Asian American Literature." Signs 25.1 (Autumn 1999): 171-226. JSTOR. Web. 23 Dec. 2016 .

$\mathrm{Xu}$, Wenying. "Sticky Rice Balls or Lemon Pie: Enjoyment and Ethnic Identities in No-No Boy and Obasan." LIT: Literature Interpretation Theory 13.1 (2002): 51-68. Web. 29 Nov. 2017.

Yogi, Stan. "'You Had to Be One or the Other': Oppositions and Reconciliation in John Okada's No-No Boy." MELUS 21:2 (Summer 1996): 63-77. JSTOR. Web. 21 March 2017.

Yoon, Seongho. "No Place in Particular": Inhabiting Postinternment America, Articulating Postinternment Anxieties in John Okada's No-No Boy" Ariel 43.1 (2012): 45-65. Web. Sept. 2017. 
Heterotopia and the Failure of Pluralism in the Post-Internment Era: A Foucauldian Reading of John Okada's No-No

Zhang, Benzi. "Mapping Carnivalistic Discourse in Japanese-American Writing." Asian American Literature 24.4 (Winter 1999): 19-40. JSTOR. Web. 23 Feb. 2017. 